lamps. Life-test frames, designcd for dealing with large numbers of lamps, have been constructed in the laboratory; the racks can be tilted, so that the lamps may be burnt at any angle, and resistances are provided for each lamp to bring the voltage on the terminals to the value at which the lamp will run initially at the standard watts per candle. A new specially designed photometer bench, by Alex. Wright and Co., is employed for rapid candle-power measurements of lamps under life test.

Following upon a suggestion made by Dr. Glazebrook at the British Association meeting in Dublin, agreement has been arrived at with the standardising iaboratories of some other countries in regard to the adoption of an international light unit, and it is hoped that from an early date it may be possible to express light measurements in terms of the international candle. The matter is engaging the attention of the International Electrotechnical Commission.

The metrology division has been much occupied during the year in transferring apparatus to the new building completed in 1907. A special feature of the building is the long gallery, in which 50-metre surveying tapes can be verified, whether on the flat or in catenary. Special apparatus for the measurements has been constructed by the Cambridge Scientific Instrument Co., and the installation is now nearly complete.

One of the rooms in the metrology building will be devoted to the apparatus for ruling diffraction gratings which belonged to the late Lord Blythswood, and which has been placed on loan at the laboratory by Lady Blythswood. After some alterations which were contemplated by Lord Blythswood, the apparatus will be capable of ruling gratings up to a length of 8 inches.

As in previous years, the division has undertaken a considerable amount of work in connection with the Engineering Standards Committee, and in particular diring rgo8 important work has been done on the measurement of screws and screw gauges.

In the engineering department Dr. Stanton is still continuing his very valuable and interesting researches with regard to wind pressure. His paper relating to the wind pressure on structures in the open, and discussing the difference in the resultant pressure on large and small plates, is included in vol. v. of the " Collected Researches." The question considered during 1908 has been the possibility of inferring the maximum pressure on a large area during a gale from the maximum pressure registered at a single point of the area. The attempt to measure the mean pressure over a large area of rooo square feet was made by means of pressure tubes distributed over the area, and some interesting theoretical results were obtained when a self-recording apparatus was set up to register the mean pressure from more than two such tubes. At present continuous records are being taken of the mean pressure at two points 40 feet apart, and will no doubt furnish information of value. Dr. Stanton has also been investigating the resistance of plates and models in a uniform current of water. Some of the results obtained are included in a communication to be made to the Institution of Naval Architects. A research on the heat transmission and resistance of air currents in pipes is also in progress.

The important work on the behaviour of materials under repeated stresses has been very considerably advanced. An ingenious machine has been devised to make a combined abrasion and bending test under conditions approximating to those of a steel rail in practice; the conditions may be varied from pure abrasion to pure bending. A paper on the resistance of materials to impact was read before the Institution of Mechanical Engineers, and Mr. Bairstow has completed a research on the elastic limits of material under alternating stress.

The work on superheated steam has been continued, and in connection with this a research has been carried out on the loss of heat from steam-pipe flanges.

In both branches of the work of the department of metallurgy and metallurgical chemistry material progress has been made. A paper on cooling curves was read by $\mathrm{Mr}$. Rosenhain before the Physical Society; a paper entitled " Eutectic Research, No. r, the Alloys of Lead and Tin," was presented to the Royal Society and printed in the
Philosophical Transactions, and the research on the copperaluminium-manganese alloys for the Alloys Research Committee of the Institution of Mechanical Engineers was carried on continuously throughout the year. A report on the first section of this work will shortly be communicated to the institution. In addition, a considerable number of important cases of failure were investigated in cooperation with the engineering department, and some account of this work was given in a paper on the study of breakages, read before Section $\mathrm{G}$ of the British Association at Dublin.

In the section of this department devoted to metallurgical chemistry, special attention has been given to the improvement of the equipment and to the organisation of the work. The methods of steel analysis and the apparatus employed were described in a paper read by $\mathrm{Mr}$. Rosenhain before the Iron and Steel Institute, which is reprinted as an appendix to the laboratory report. Of special interest are the silica-tube combustion furnaces for the estimation of carbon, a new type of electric muffle furnace, and the apparatus for electrolytic deposition. New methods of analysis have been investigated, and an improved procedure for the estimation of phosphorus, especially in phosphor-tin, has been described by Messrs. Gemmell and Archbutt.

The work done at the observatory department under Dr. Chree, and the allied work at Eskdalemuir under Mr. Walker, are of special character, and cannot properly be dealt with here. Dr. Chree has completed a monumental piece of work in the reduction and analysis of the magnetic records obtained by the Discovery Antarctic Expedition, while in addition he has discussed the magnetic observations of the Scotia and the temperature and pendulum observations of the Discovery. His work on the Kew records has been continued in a paper, "Magnetic Declination at Kew Observatory, 1890 to I900," Phil. Trans., A, vol. ccviii., 1908, reprinted in vol. v. of the "Collected Researches"; a similar discussion of the horizontal force curves is in progress. Much attention is also being given to the improvement of methods of meteorological observation.

The new observatory at Eskdalemuir was occupied in May, 1908, and the work of installing apparatus was at once commenced. Regular meteorological observations are now proceeding, and the seismographs have been running since September, but the magnetographs have not yet been erected. The delay has been due chiefly to difficulties with damp in the magnetograph houses, which, however, it is hoped are now finally overcome. Absolute magnetic observations have been made three times weekly since October.

The past year has been marked by steady and continuous progress in all branches of the work of the laboratory rather than by any new development of first-rate importance. The construction of the experimental tank will add to the laboratory a new department of special interest, and it is to be hoped that in the near future means may be found of providing the much-needed extensions of existing departments.

THE AËRO AND MOTOR-BOAT EXHIBITION. THIS exhibition, which opened at Olympia on March 19 and will close on March 27 , is the first of its kind to be held in this country. The exhibition has been organised by the Society of Motor Manufacturers and Traders, Ltd., of which Mr. E. Manville is president, and is under the management of Mr. H. A. Blackie. The society has had the cooperation of the Aëro Club, and has succeeded in presenting a valuable collection of models of aëroplanes, several full-sized complete machines, together with ordinary and dirigible balloons, and motor-boats.

Probably the most striking object in the hall is the inflated Wellman dirigible America. This airship, in which Mr. Wellman proposes again to attempt to reach the North Pole this year, is about 184 feet long, 52 feet in diameter, and about 70 feet from the top of the envelope to the bottor of the basket. The ship is suspended from the roof of the hall, and has a capacity of 300,000 eubic feet. The car is 125 feet long, the base forming a petrol tank of

NO. 2056, VOL. 80] 
two tons capacity. Provision is made for three explorers, a pack of dogs, two sleds, a boat, \&c., and, when completely equipped, the ship weighs about five tons.

Owing to the few opportunities of inspecting aëroplanes in this country in the past, these machines at Olympia are easily first in public interest. Included among them is the aëroplane, of French make, used by Mr. J. T. C. MooreBrabazon, who was one of the first two Englishmen actually to fly. The machine is a bi-plane, i.e. two planes one above the other, built by Voisin, there being 2 metres' distance between the planes, and it is fitted with an eight-cylinder E.N.V. engine. Three flights of from one to two kilometres, and about a dozen flights of from one to five kilometres, at a height up to 50 feet, have been made with this machine.

The Société Commercial des Automobiles Gobron-Brillie show an unfinished Breguet aëroplane of the bi-plane type. This machine is fitted with means of warping the planes differentially, which is intended to produce automatic balancing, to facilitate turning, and to act as an elevating
rudder.

A British-made aëroplane, designed by $\mathrm{Mr}$. Weiss, is shown by Handley Page, of Woolwich. The machine is a monoplane, having a span of 34 feet and an area of 150 square feet. There are two propellers driven by a 12 horsepower three-cylinder motor, air-cooled. Steering is effected by means of two flaps placed at the back of the main plane.

The Miesse Petrol Car Syndicate show a machine having wings, which are given a bird-like movement by an ingenious mechanism. Messrs. Short Brothers, of Battersea, show a bi-plane, and also an inflated balloon of 11,000 cubic feet capacity constructed for the Hon. C. S. Rolls. A bi-plane designed by W. Windham, of St. John's Hill, is shown, but, like several of the other machines, has not yet been tried. The Continental Tyre and Rubber Co., of Clerkenwell Road, show an inflated passenger balloon of 49,000 cubic feet capacity.

Mr. Howard T. Wright, of Marylebone, shows a beautifully constructed bi-plane, the main planes being 40 feet wide and 6 feet 6 inches deep. There are two propellers running in opposite directions driven by a 20 horse-power motor. Vertical steering is provided for by a double rudder in front of the main planes, and horizontal steering by a vertical rudder in the tail. Messrs. Lamplough and Son, Ltd., of Willesden Junction, show a compound lifter plane and glider. The design is the first of its kind, and awaits trial.

Mr. Frederick R. Simms shows a Simms-Voisin bi-plane of the type used by Farman, Delagrange, and Fournier in their flights. The main planes are 32.8 feet long, 6.5 feet wide, 5 feet space; the rudder cell or tail is 8.5 feet wide, 5 feet space, and contains a vertical rudder for horizontal steering. Vertical steering is secured by a horizontal rudder in front of the main planes. The total length is 37.8 feet; the weight complete is $1500 \mathrm{lb}$. The 50 horsepower motor has six cylinders, and weighs $528 \mathrm{lb}$. complete with water and petrol for a two hours' run. The propeller is 7 feet 5 inches diameter, 5 feet pitch, and weighs $33 \mathrm{lb}$.

An R.E.P. monoplane is shown by the Etablissement Robert-Esnault-Pelterie. This machine won third prize for 200-metre flight last year, the wind having a speed of 6 metres to 8 metres. A Delagrange bi-plane, by Voisin, is shown by the Mass Cars firm. The Cody war kite is on view by permission of the War Office. Messrs. Willows show a dirigible balloon built at Cardiff. Conspicuous among the exhibits of motors are those of the Wolseley Tool and Motor Car Co., Ltd., and also those of Messrs. John I. Thornycroft and Co., Ltd. It is unfortunate that no machine used by the Wright brothers is on view, although a small model of one may be scen.

The exhibition is well worth a visit, and shows that manufacturers in this country are alive to the potentialities of recent developments in France and other countries, and are taking steps not to be left behind in the race for the conquest of the air. It will assist in arriving at a proper estimation of the value of the exhibition if the fact is realised that all is as yet in the experimental stage, even in the case of the most successful of the machines shown.

\section{HIGHER EDUCATION IN THE UNITED} STATES.

THE report of the U.S. Commissioner for Education for the year ended on June 30 , 1907, has been received from Washington. This is the first report issued by Dr. Elmer E. Brown, who succeeded Dr. William T. Harris as commissioner on July 1,1906 . The two volumes, which together run to 1214 pages, deal exhaustively with every branch of American education, and in addition include valuable reviews of educational progress in many European and other countries.

The carefully arranged and remarkably complete tabulated statistics of the 606 universities, colleges, and technological schools of the United States, contained in the second volume, shows what valuable assistance our own Board of Education could render students and administrators of education if it would provide similar conspectuses concerning British institutions of higher learning.

From this part of the report we learn that the total value of all gifts and bequests reported by the 606 institutions referred to, as having been received during the year under review, amounted to $4,574,000 l$. Of this amount about $\mathrm{I}, 540,000 \mathrm{l}$. was given for buildings and improvements, and 2,540,00ol. for endowment. The remaining amount was for current expenses. Forty-two institutions each received $20,000 l$. or more. The six institutions which benefited to the largest extent in this way were the University of Chicago, which received some $1,189,000 \mathrm{l}$; the Rensselaer Polytechnic Institute, of New York, with its 215,400l.; Yale University, 198,00ol.; Cornell University, 156,0ool.; Princeton University, New Jersey, 153,00ol.; and Harvard University, $\mathbf{1 3 9 , 0 0 0 l .}$

The report shows that the Washington Bureau of Education received full particulars for the year which ended in June, 1907, from 606 universities, colleges, and technological institutions in the United States. Of these institutions, 150 are for men only, and 330 are open to both men and women. The teaching force of the whole of the institutions aggregated 24,679 - an increase of 729 teachers of different grades over the preceding year. The total enrolment of students was 293,343. Leaving out colleges for women only, and dealing with the remaining 480 institutions, tables are provided in the report which show that, in the session 1906-7, 3,399,00ol. was received by students' fees, $782,000 l$. being for board and other noneducational purposes.

The amount received from productive funds was $\mathrm{x}, 955,000 l$. $;$ the receipts from State or city for increase of plant were $755,000 l$., for endowment $45,000 l$, and for current expenses $1,628,000 l$. From the United States Government certain of the institutions, including agricultural and mechanical colleges, received 533,0ool. The grand total of the receipts of these 480 colleges from every source was $13,616,000 l$. Exclusive of amounts for endowment purposes, the total sum available for current expenses, improvements, and building was $11,08_{3}, 000 l$. These institutions had in the year under review in their libraries $12,472,530$ volumes, valued at about $3,6 r_{3}, 000 l$. The value of their scientific apparatus, machinery, and furniture was $5,639,000 l$., and of grounds and buildings 48,8 r6, oool., while their productive funds reached $50,238,000 l$.

Some aspects of higher education in the United States are dealt with in an article by Prof. R. C. Maclaurin, president-elect of the Massachusetts Institute of Technology, which appeared in the Revue scientifique of January I6 under the title "L'Enseignement technique superieur aux États-Unis." After referring to the interest taken in France in the progress of technological education, Prof. Maclaurin remarks that the European suspects an excessive development of the utilitarian spirit across the Atlantic, and thinks that America's enthusiasm for her own institutions too often displays some lack of the critical faculty ; but it is maintained that a good deal of the right spirit is at work, and that the problems of education in America are being attacked with seriousness and strength of purpose. Referring to the better technological institutions in the United States, the article points out that judged by French standards, the expense of conducting 